\title{
Analysis of Factors Affecting Household Income of Waste Bank Customers in Medan City
}

\author{
Rifqah Harahap \\ Faculty of Economics, Universitas Negeri Medan, Indonesia \\ Muhammad Fitri Rahmadana \\ Faculty of Economics, Universitas Negeri Medan, Indonesia \\ Eko Wahyu Nugrahadi \\ Faculty of Economics, Universitas Negeri Medan, Indonesia
}

\begin{abstract}
Income is one indicator to measure the welfare of a person or society. In this study, the household income of waste bank customers is classified as low and medium income. Many factors cause a person has low-income; one crucial aspect is the type of work, the outpouring of work time and others. The purpose of this study was to analyze and determine the effect of the outpouring of work time, waste sale prices, age of workers, number of household members, work experience and radius of waste collection toward the household income of customers of waste banks in Medan City. The data used in this study are primary data with a total sample of 120 customers with the sampling technique of respondents conducted by cluster random sampling and data collection techniques using questionnaires. The data analysis model used is multiple linear regression. The results of this study indicate that the outpouring of work, the selling price of waste, and the number of household members have a positive and significant effect on the household income of the waste bank customers. The age of the worker has a positive and insignificant effect on the household income of the waste bank customers. Whereas work experience and radius of waste collection have a negative and insignificant effect on the household income of waste bank customers.
\end{abstract}

Keyword : Revenue, outpouring of work time, selling price of waste, age of worker, number of household members, work experience, radius of waste collection, waste bank.

\section{INTRODUCTION}

Economic development is an effort to develop economic activities to enhance the level of income and welfare of a just and prosperous society. One indicator of achieving the development goals is the level of income of the population. A better quality of life does require higher income, but what is needed is not only that. The higher income is only one of the many conditions that must be met (Todaro, 2000).

The high and low the levels of human life can be known through income, but income also depends on the natural resources and human resources; therefore economic development requires the optimal mobilization of natural resources and human resources (Giang, 2013). Parameters that can be used to measure the level of living or prosperity of a society are determined by per capita income. Per capita Gross Regional Domestic Product (GRDP) is an illustration of the average income that each resident might receive as a result of a one-year production process. Per capita income is calculated by eliminating gross factors which consist of depreciation and net indirect tax, as well as added net income that enters the region, so that 
per capita income is considered closer to the actual income situation in the community (BPS, 2018).

Table 1. GRDP Per Capita of Medan City at Current Prices and Based on 2010 Constant Prices, 2013-2017 (Million Rupiah)

\begin{tabular}{|c|c|c|c|c|}
\hline \multirow{2}{*}{ Year } & \multicolumn{2}{|c|}{ Current Prices } & \multicolumn{2}{c|}{ Constant Prices } \\
\cline { 2 - 5 } & Value & Growth & Value & Growth \\
\hline$(1)$ & $(2)$ & $(3)$ & $(4)$ & $(5)$ \\
\hline 2013 & $61.626,63$ & 11,34 & $51.882,27$ & 4,72 \\
\hline 2014 & $67.400,47$ & 9,36 & $53.637,87$ & 3,38 \\
\hline 2015 & $74.471,41$ & 10,49 & $56.218,28$ & 4,81 \\
\hline $2016^{*}$ & $83.452,21$ & 12,05 & $59.236,74$ & 5,36 \\
\hline $2017^{* *}$ & $90.993,01$ & 9,03 & $62.173,47$ & 4,96 \\
\hline
\end{tabular}

Source : Medan BPS, 2018

Keterangan : *) Temporary number, ${ }^{* *}$ ) Very temporary number

From the data in Table 1, it shows the Gross Regional Domestic Product (GRDP) per capita of Medan at current prices in 2013 amounted to 61.62 million rupiahs and increased to 90.99 million rupiahs in 2017. When viewed according to current prices, the figure is year to year shows an increase. Meanwhile, when viewed from the calculation based on constant prices in 2010, then in the period 2013-2017 there was a relatively steady increase. In 2017, the Gross Regional Domestic Product (GRDP) per capita of Medan City was based on constant prices reaching 62, 17 million rupiah.

This condition shows that the level of per capita income in Medan is relatively reasonable but still needs to be improved in the quality of distribution so that income distribution is more evenly distributed and in the end it can reduce the remaining poverty rate (BPS, 2018). Revenue is one indicator to measure the welfare of a person or society so that this community income reflects the economic progress of society (Lumintang, 2013). Whereas according to (Mankiw, 2012), income is income received by households and businesses that are not companies. This statement is following what was stated by (Mubyarto, 2005), that income is the result of money or other material.

The Medan City Government and with the support of the community set up an informal waste recycling sector, namely an organization or institution in the economic field that develops one method of 3R activities (reduce, reuse and recyle) called a waste bank. Until now four Waste Banks are still actively operating in the city of Medan, which was established by the Sanitation and Landscaping Service of Medan City. Medan City is the third largest city in Indonesia, which has a population of around 2,229,408 people and households of around 511,515 with support from 21 sub-districts spread throughout the region. As population increases, changes in technology and the economy, as well as changes in the pattern of consumption of the population causes waste production to increase every day.

Family dependence is one factor for earning income. The more children and dependents they have, the more time they will have to work. The size of the household states the number of all members who are dependent on the household. Income is a very urgent issue because one of the benchmarks of a community's high and low standards of living can be seen from its ability to fulfill the most basic needs (consumption) according to each household. The ability to fulfill basic needs is very closely related to the income earned. Whether the income received by the community has fulfilled its basic needs or not. 


\section{Household Income}

\section{LITERATURE REVIEW}

Revenue is one of the essential components of the economy. This income can indicate the level of welfare of a household. (Samuelson, 1948), says income is an acceptance for a person or group from the results of donations, both energy and mind are poured out so that they will receive remuneration. Revenue shows all money or other material results achieved from the use of wealth or services received by someone or household during a specific period in economic activity (Winardi, 1998).

(Semaoen \& Kiptiyah, 1997) state that the source of household income is classified into four, namely: (1) income in business, (2) income outside of business, (3) income earned from workers, (4) remittances, namely income obtained by the household comes from one household member who works outside the village. According to Jaya (2011), the income or income of a citizen is a sale of output produced in a production process. Income or profit is the difference between total revenue and total costs. Where the costs consist of fixed costs and non-fixed costs.

Total revenue is the overall revenue from the sales proceeds from the output produced. Total revenue generated from the amount of output sold multiplied by the price of goods sold, can be explained in the equation as follows:

$$
\mathrm{TR}=\mathrm{P} \times \mathrm{Q}
$$

Explanation :

$\mathrm{TR}=$ Total Revenue

$\mathrm{P}=$ Price of goods sold

$\mathrm{Q}=$ Amount of goods sold

From sales, informal sector actors will receive income of TR, the amount of TR can be known through the sale of goods from the informal sector actors themselves, (Pratama, 2016).

According to (Pramika, 2017) the factors that influence the increase in household income are : Level of education

The involvement of someone in the education process or the level of education influences and shapes patterns and frameworks of thinking, perception, understanding, and personality. Based on this, it can be seen that education is expected to provide changes in individuals, households, and countries in various fields including the economy.

\section{Type of business}

Work as a business carried out by someone, either themselves or with other people, to produce a commodity or service to obtain income.

\section{Number of family members}

The number of family members owned by a household has two impacts. On the consumption side, it adds to expenditure, thus providing additional costs that constrain households to increase per capita income. Meanwhile, from the context of production, the number of family members is a part that can help increase income because it is a factor of production.

\section{Age}

Age is distinguished based on productive and non-productive age. The non-productive age is the pre-old age limit of 50 years and more 


\section{Length of working}

(Becker, 2012) suggested a new approach to time allocation theory with different activities. The usefulness of time is distinguished based on how much the hourly expense is used for each activity carried out. Therefore, the time used today is more careful compared to past time. Market value from relative time is higher than the price of goods.

\section{Workforce}

Each household workforce is expected to work or not. If you choose to work, it means you will give higher income value and will devote more time to achieving consumption needs. Conversely, if it does not work, the relaxed time will have a use value higher than income.

Whereas according to (Mulyanto, 1991), the high and low income of the community is influenced by several other factors, including the type of work or position, education, tenure, and number of family members.

\section{Household Economic Model}

(Becker, 2012) developed a theory to study household economic models, where production and consumption activities are not separate, and the use of family labor is preferred. This theory views households as decision makers in production and consumption activities and their relationship with time and income allocations analyzed simultaneously. Becker also made revisions to neo-classical economic theory, especially those originating from Marshallian. $\mathrm{He}$ built a household economic model in which income is endogenous, whereas in Marshallian model income is exogenous. This assumption in income characteristics has essential implications for supply theory that has been developed by Neo-classics (Pollak, 2002).

The neo-classical economic model, analysis of consumption is separable with production decisions sourced at separate stages of analysis, pure consumers and pure producers. Therefore what is done by (Becker, 2012) and (Singh, 1986) is to loosen the assumptions used by neo-classical economists in analyzing household economic behavior. (Singh, 1986) see that the household budget is endogenous, whereas in the Marshall model the budget is considered to be exogenous. (Becker, 2012) builds the theory of household economics by relaxing the Marshall model which is considered endogenous household income. As in the Marshall model, households are considered to increase their welfare through maximizing the utility of the utility they obtain from the consumption of various commodities. In the Becker and Sigh et al. Models, relaxed time is considered a form of consumption. Therefore, households do not only consume physical commodities, but they also affect other physical commodities.

The formula compiled by (Becker, 2012) looks at the behavior of household consumption as a process in two levels, namely: (1) Explain the behavior of households facing a production function where the time and capital available in the household are used to produce goods and services that can be consumed by the household. (2) Studying the decision process of consumption choices of household members behaves as individual behavior. Thus households in maximizing their satisfaction are limited by production, time and income constraints. These constraints are formulated as follows:

\section{Outpouring of Household Work Time}

Analysis of working hours is part of microeconomic theory, especially in the theory of labor supply, which is about the availability of individuals to work in the hope of earning income or not working with the consequences of sacrificing the income they should get. The willingness of workers to work long or short hours is an individual decision. Jones G and Bondan 
Supraptilah divide the working hours of a person in one week into three categories, namely (Ananta \& Hatmaji, 1985):

a. Someone who works less than 35 hours a week. If someone works under 35 hours per week, he is categorized as working under regular hours.

b. Someone who works between 35 to 44 hours per week, if someone works between 35 to 44 hours per week, then he is categorized as working regular working hours.

c. Someone who works above 45 hours per week. If someone works above 45 hours per week, he is categorized as working long hours.

\section{Waste Bank Program}

According to the Republic of Indonesia Law No. 18 of 2008 concerning Waste Management Article 1 "Waste is the remainder of daily human activities and / or natural processes in the form of solids". Waste bank is a place to save waste, where the waste saved in a waste bank is waste that has economic value. Waste that has economic value or selling value is waste that can be reused and can be recycled into a new product. If in general banks are deposited in the form of money, while in banks the waste deposited is in the form of waste which has been sorted according to the type of waste and has economic value.

Waste Bank Management imitates the model of one bank based on its function, a savings bank. The collection of funds in the waste bank is in the form of savings containing the results of waste collection by customers that have been grouped into bottled, paper, and plastic waste that has been valued in Rupiah. According to (Ruski, 2014) "Just as in money-saving banks, customers, in this case, the community can immediately come to the bank to deposit. Not money deposited, but the waste they deposited. The waste is weighed and recorded in the account book by the waste bank officer. In a waste bank, there is something called waste savings".

Whereas waste handling is applied in waste recycling activities. According to (Tadir \& Trie, 2011) Waste Recycling is "The process of making a used material into a new material to prevent waste, which can be something useful when compared to the process of making new goods." Waste is recycled into handicraft items that can be resold in forms such as bags, wallets, and tissue boxes.

\section{The Relationship Between Waste Selling Prices and Income}

Not every waste that is disposed of by the community is worthless. Some types of waste have a return value, and some can be reused, such as bottles, paper/cardboard, plastic, cans, iron, and aluminum. Besides, wet waste such as organic waste can also be stockpiled as compost for garden plants. The economic value of waste management generally comes from two sectors, namely: (1) The formal sector, namely the economic value sector managed by the government, and (2) The informal sector, namely the economic value sector managed by waste collectors.

In the opinion of (Case \& Fair, 2006) the selling price will determine and measure how much income will be received. This statement indicates that the higher the price level, the better the effect on the net income received. According to (McConnell, 1990), the selling value of waste is the advantage of recycling waste products the volume of waste generated by the selling price of waste (quantity $\mathrm{x}$ price). The intended volume of waste generation is the amount of inorganic waste that has been successfully ported and collected by scavengers obtained from the source of waste and then deposited to large collectors in the study area. The selling price is the highest selling price of waste given by a large collector (price). 


\section{Relationship Between Age of Workers and Income}

According to (Branson, 1979), the size of a person's income level is influenced by age. In the early years of his life, a person's income will be smaller than his consumption needs and to sustain his life, and he will try to find debt. Sometime later after he gets a particular position in his job, his income will increase to an absolute peak. When it reaches the peak of income, it is in the middle year of life. During this surplus period, a person can save to meet life later in old age, because his income is higher than his consumption. After reaching the bottom of a person's income decreases in line with the decline in age and productivity. After a person retires, his income decreases and his consumption needs are higher than his income. At times like this people can maintain their lives by utilizing their savings.

\section{METHODOLOGY}

The scope of this research is to analyze the effect of the outpouring of work time, waste sale price, age of worker, the number of household members, work experience and radius of waste collection on the income of household customers of waste banks in Medan City. This research was conducted in Medan City. Because Medan City has a Waste Bank and is located in several sub-districts. This condition attracted the interest of researchers to come directly to the location because the Waste Bank aims to help reduce waste and to make people aware of a healthy, neat, and clean environment. A waste bank was also established to convert waste into something more useful in the community, for example for handicrafts and fertilizers that have economic value and can increase the income of customers who save waste at the bank.

The sampling technique chosen in this study used random cluster sampling. Cluster random sampling is used when the population consists of individual groups or clusters. Regional sampling technique is used to determine the sample if the object to be studied or the data source is comprehensive. The sample of this study was the customers of the waste bank in the city of Medan. In determining the amount of the number of samples can use the Slovin formula with a confidence level of 95\%, and an error rate of 5\% (Sevilla, 1993).

Table 2. Samples of Waste Bank Customers in Medan City

\begin{tabular}{|c|c|c|c|c|}
\hline No. & Name of waste bank & Sub-district & $\begin{array}{l}\text { Number of } \\
\text { Customer }\end{array}$ & Sample \\
\hline 1. & Bank Sampah Aulia & Medan Sunggal & 30 & 21 \\
\hline 2. & Bank Sampah Mawar & Medan Kota & 20 & 14 \\
\hline 3. & Bank Sampah Melati & Medan Amplas & 30 & 21 \\
\hline 4. & Bank Sampah Mutiara & Medan Denai & 91 & 64 \\
\hline \multicolumn{3}{|c|}{ Total } & 171 & 120 \\
\hline
\end{tabular}

So, the study sample for a population of 171 customers with an error rate of $5 \%$ and a $95 \%$ confidence level is 120 customers. Data collection in research is intended to obtain relevant and accurate materials. The data used in this study are primary data. The method used in data collection in this study is: Questionnaire which is data collection by distributing questionnaires or list of questions to waste bank customers to obtain the necessary data.

\section{Analytical Method Descriptive Analysis}

The descriptive analysis serves to describe or give an overview of the object under study through a sample fund or population as it is, without analyzing and making generally accepted conclusions. Another descriptive analysis that will be carried out in this study is the marketing margin analysis carried out by recycling businesses, namely, waste banks. 
The marketing flow of waste from collectors to processing factories is related to the price of each product so that the amount of added value is known after the collection and sale of waste and its marketing flow. Then calculated marketing margins, profit margins and prices received by waste collectors. According to (Rahayu, 2004), it was systematically formulated as follows:

$$
M P=P r-P f
$$

Explanation, MP: Waste marketing margin; Pr: Price of marketing sales at the consumer level; Pf : Marketing purchase prices at the producer level

\section{Regression Analysis}

The analytical model used to identify the revenue function of customers of Waste Banks in Medan City is an analysis model using quantitative methods Multiple Regression with Ordinary Least Square (OLS) method to get multiple regression line coefficients. As the dependent variable in this study is the income of customers of the Waste Bank in Medan City, and the independent variable (independent variable) is the outpouring of work time, household consumption, household workforce, age of the worker, number of household members work experience and radius of waste collection. In this study, the function of income of customers of Waste Banks in the City of Medan can be analyzed by mathematical functions as follows:

$$
\text { Income }=F\left(X_{1} X_{2} X_{3} X_{4} X_{5} X_{6}\right)
$$

Then the function is transformed into the econometric equation model with the model specification :

$$
(P N B S)=\alpha+\beta_{1}(C W K)+\beta_{2}(H J S)+\beta_{3}(U P)+\beta_{4}(J A R T)+\beta_{5}(P K R)+\beta_{6}(R P S)+\epsilon
$$

\section{Explanation :}

PNBS: Household Income of Waste Bank Customers, CWK: Outpouring of Work Time, HJS: Waste Selling Price, UP: Age of Worker, JART: Number of Household Members, PKR: Work Experience, RPS: Waste Collection Radius, $\beta 0$ : Intercept / Boarding, $\beta 1 \beta 2 \beta 3 \quad \beta 4 \beta 5 \beta 6$ : Regression coefficient, e: Error term, t: Time.

\section{RESULT}

\section{Characteristics Description of Research Respondents}

The instrument used in this study was a questionnaire. This research was conducted by distributing questionnaires to 170 respondents. Based on the research data that has been collected, the data obtained about the characteristics of respondents in this study consisted of (1) gender, (2) age, (3) level of education, (4) basic work, (5) status of home ownership and (6) number of family members.

Figure 1. Gender of Respondents

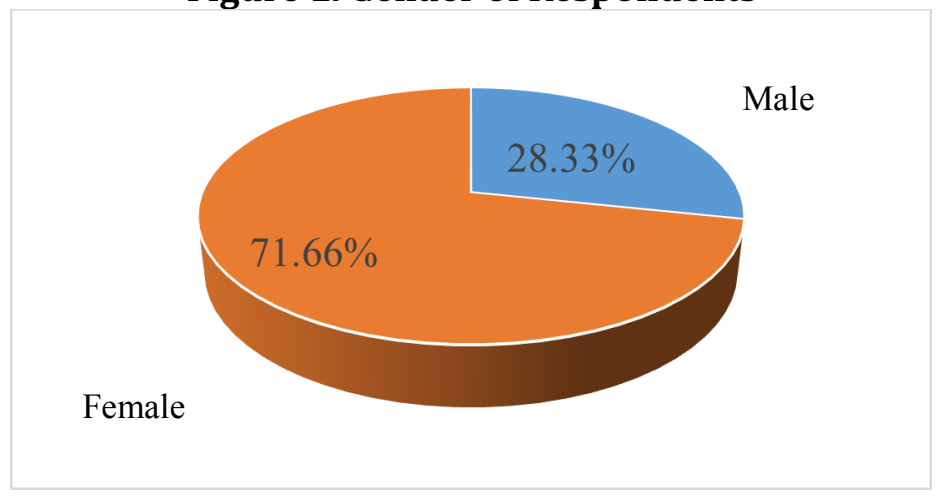


From the Figure 1, it can be concluded that the majority of respondents of waste bank customers are dominated by female as many as 86 people or equal to $(71.66 \%)$ and man as many as 34 people or equal to $(28.33 \%)$.

Table 3. Age of Respondents

\begin{tabular}{|c|l|c|c|}
\hline No & Age & Frequency & Percentage \\
\hline 1 & $\leq 26$ years old & 2 & 1,67 \\
\hline 2 & $27-40$ years old & 53 & 44,16 \\
\hline 3 & $41-55$ years old & 54 & 45,00 \\
\hline 4 & $56-65$ years old & 11 & 9,17 \\
\hline \multicolumn{2}{|c|}{ Jumlah } & 120 & 100 \\
\hline
\end{tabular}

From the data, it can be explained that most of the respondents who are customers at the waste bank in Medan City are 41-55 years old, as many as 54 people or around (45.00\%), then followed by respondents aged 27-40 years as many as 53 people or around (44.16\%) as well as respondents with ages above 55 - 56 years as many as 11 people or around $(9.17 \%)$ and those with at least 26 years old as many as 2 people or around (1.67\%).

\section{Marketing Margin Analysis}

Analysis of marketing margins is seen from the purchase price of waste from the distribution channels of waste bank customers, waste banks, big agents, to the level of recycling factory. The bank's customer margin marketing is calculated from the difference in purchase price/kg of waste at the factory level with the purchase price/kg of waste at the level of the waste bank customer. The following is the margin table for the customers of the waste bank.

Table 4. Marketing of Waste Bank Line Margin (in Rupiah/kg))

\begin{tabular}{|l|c|c|c|c|}
\hline \multirow{2}{*}{\multicolumn{1}{c|}{ Types of goods }} & \multicolumn{4}{c|}{ Market Actor } \\
\cline { 2 - 5 } & Customers & Waste Bank & Big Agent & Factory \\
\hline Cardboard & 1.000 & 2.000 & 2.500 & 3.000 \\
\hline Book & 1.000 & 1.800 & 2.000 & 3.000 \\
\hline Newspaper & 1.000 & 2.500 & 3.000 & 3.500 \\
\hline Used HVS / Opaque paper & 1.000 & 2.000 & 2.500 & 4.000 \\
\hline Magazine & 600 & 1.200 & 1.500 & 2.000 \\
\hline Duplex & 400 & 600 & 900 & 1.000 \\
\hline Bucket & 1.500 & 2.000 & 2.500 & 2.800 \\
\hline Solid Iron & 2.500 & 3.000 & 4.000 & 5.000 \\
\hline Iron cabin & 2.000 & 2.500 & 3.500 & 4.500 \\
\hline Aluminum & 8.000 & 9.000 & 9.500 & 10.500 \\
\hline Bottles / Glass of mineral water & 3.000 & 3.500 & 5.000 & 5.500 \\
\hline Bottle scales & 100 & 200 & 300 & 400 \\
\hline Sack & 1.000 & 1.500 & 2.500 & 3.000 \\
\hline Battery & 4.000 & 5.000 & 6.000 & 50.000 \\
\hline
\end{tabular}

From table 4.6, the calculation of the marketing margin for waste bank customers in each type of waste / $\mathrm{kg}$ is as follows:

Margin marketing for waste bank customers $=$ Pr - Pf
1) Cardboard
$=$ Rp. 3,000 - Rp. $1,000=$ Rp. 2,000, - 

2) Books
$=$ Rp. $3,000-$ Rp. $1,000=$ Rp. 2,000, -
3) Newspaper
$=$ Rp. $3,500-$ Rp. $1,000=$ Rp. $2,500,-$
4) Used HVS / Opaque paper
$=$ Rp. $4,000-$ Rp. $1,000=$ Rp. 3,000, -
5) Magazine
$=$ Rp. $2,000-$ Rp. $600=$ Rp. $1,400,-$
6) Duplex
$=$ Rp. $1000-$ Rp. $400=$ Rp. 600 , -
7) Buckets
$=$ Rp. $2,800-$ Rp. $1,500=$ Rp. $1,300,-$
8) Solid iron
$=$ Rp. $5,000-$ Rp. $2,500=$ Rp. $2,500,-$
9) Cabin iron
$=$ Rp. $4,500-$ Rp. $2,000=$ Rp. $2,500,-$
10)Aluminum
$=$ Rp. $10,500-$ Rp. $8,000=$ Rp. 2,500, -
11)Bottles / glasses of mineral water $=$ Rp. 5,500 - Rp. 3,000 = Rp. 2,500, -
12)Bottle scales = Rp. $400-$ Rp. $100=$ Rp. $300,-$
13)Sacks
14)Battery
=Rp. 3,000 - Rp. $1,000=$ Rp. $2,000,-$
$=$ Rp. 50,000 - Rp. $4,000=$ Rp. 46,000,-

The average MM of waste bank lines = Rp. 5.078,- $/ \mathrm{kg}$

From the calculation, the marketing margin of the waste bank line was obtained with an average marketing margin of fourteen types of waste above reaching Rp. 5,078,- / kg.

\section{Results of Multiple Linear Regression Estimates (OLS)}

This study uses primary data. Regression testing used in this study uses cross section data.

Table 5. Regression Estimation Results with Multiple Linear Methods

\begin{tabular}{|c|c|c|c|c|}
\hline Variable & Coefficient & Std. Error & t-Statistic & Prob. \\
\hline $\mathrm{C}$ & -14.86628 & 3.597661 & -4.132208 & 0.0001 \\
\hline CWK & 0.274107 & 0.127579 & 2.148536 & 0.0338 \\
\hline HJS & 2.357574 & 0.137972 & 17.08731 & 0.0000 \\
\hline UP & 0.404258 & 0.472624 & 0.855349 & 0.3942 \\
\hline JART & 0.554516 & 0.430934 & 1.286778 & 0.0448 \\
\hline PKR & -0.129218 & 0.385544 & -0.335157 & 0.7381 \\
\hline RPS & -0.223335 & 0.211871 & -1.054106 & 0.2941 \\
\hline R-squared & 0.749179 & \multicolumn{2}{|c|}{ Mean dependent var } & 29.00833 \\
\hline Adjusted R-squared & 0.735861 & \multicolumn{2}{|c|}{ S.D. dependent var } & 6.455401 \\
\hline S.E. of regression & 3.317717 & \multicolumn{2}{|c|}{ Akaike info criterion } & 5.292993 \\
\hline Sum squared resid & 1243.818 & \multicolumn{2}{|c|}{ Schwarz criterion } & 5.455597 \\
\hline Log likelihood & -310.5796 & \multicolumn{2}{|c|}{ Hannan-Quinn criter. } & 5.359027 \\
\hline F-statistic & 56.25346 & \multicolumn{2}{|c|}{ Durbin-Watson stat } & 1.651878 \\
\hline Prob(F-statistic) & 0.000000 & & & \\
\hline
\end{tabular}

$$
\begin{gathered}
P N B S=-14.86628+0.274107 C W K+2.357574 H J S+0.404258 U P+0.554516 J A R T \\
-0.129218 P K R-0.223335 R P S+\epsilon
\end{gathered}
$$

From the results of the estimation model, it can be seen that the outpouring of work time (CWK), waste sale price (HJS), and household members have a positive and significant effect on household income of waste bank customers (PNSB), working age (UP) has a positive effect and not significant to household income of waste bank customers (PNBS), and work experience (PKR), radius of waste collection (RPS) has a negative and insignificant effect on household income of customers of waste banks (PNSB).

\section{CONCLUSIONS}

Partially it was concluded that the outpouring of work time variable (CWK), selling price (HJS) and household members (JART) had a positive and significant effect on the income of 
household customers of waste banks in Medan City. The variable age of workers (UP) has a positive and insignificant effect on the income of households of waste bank customers in Medan City. While the work experience variable (PKR) and radius of waste collection (RPS) have a negative and insignificant effect on the income of household customers of waste banks in Medan City. The most significant elasticity affecting the income of customers of waste banks in Medan is the variable selling price of waste with a regression coefficient of $2.3575 \%$ and followed by a variable number of household members with a variable regression coefficient value of $0.5545 \%$ and working time outflow variables with the number of coefficients regression of $0.2741 \%$. Thus it appears that the selling price of waste will have a higher influence on increasing the income of customers of waste banks in the city of Medan. Simultaneously outpouring of work time (CWK), garbage sale price (HJS), worker age (UP), household member number (JART), work experience (PKR) and radius of garbage collection (RPS), have a positive and significant effect on home income ladder of garbage bank customers in Medan City at 95\% confidence level. The coefficient of determination in this study was 0.735861 . This shows that variations in the independent variables in this case the customer's household income from saving in the waste bank and basic work can be explained by the independent variable which consists of outpouring of work time, garbage sale price, worker age, number of household members, work experience and retrieval radius garbage is $73.58 \%$, and the remaining $26.42 \%$ is influenced by other variables not examined in this study.

\section{References}

Ananta, A., \& Hatmaji, H. . (1985). Mutu Modal Manusia Suatu Analisis Pendahuluan. Jakarta: LPFE - UI.

Becker, G. S. (2012). A Theory Of The Allocation Of Time. The Economic Journal, 75(299), 493-517. https://doi.org/10.2307/2228949

BPS. (2018). Medan Municipality in Figures. Medan.

Branson, W. . (1979). Macroeconomic Theory and Policy (Second Edi). New York: Harper \& Row Publisher.

Case, K. ., \& Fair, R. . (2006). Prinsip-Prinsip Ekonomi. Jakarta: Erlangga.

Giang, R. R. (2013). Pengaruh Pendapatan Tterhadap Konsumsi Buruh Bangunan di Kecamatan Pineleng. Jurnal $E M B A, 1(3), 248-256$.

Lumintang, F. M. (2013). Analisis Pendapatan Petani Padi di Desa Teep Kecamatan Langowan Timur. Jurnal EMBA, 1(3), 991-998.

Mankiw, N. G. (2012). Principles of Microeconomics. (7th Edition, Ed.). Cengage Learning.

McConnell, R. C. (1990). Economics : Priciples, Problems, and Policy (Ed. Eleven). USA: McGraw-Hill.

Mubyarto. (2005). Pengantar Ekonomi Pertanian. Jakarta: LP3ES.

Mulyanto, S. (1991). Sumber Pendapatan, Kebutuhan Pokok dan Perilaku Menyimpang (Revisi). Jakarta: CV Rajawali Citra Press.

Pollak, R. . (2002). Gary Becker's Household Economics. (Dept. Of Economics, Ed.). Washington University In St. Louis.

Pramika, D. (2017). Faktor-Faktor Yang Mempengaruhi Pendapatan Rumah Tangga di Kabupaten Empat Lawang Provinsi Sumatera Selatan. JEMBATAN, 2.

Pratama, I. P. (2016). ANALYSIS OF FACTORS AFFECTING THE INCOME OF FISHERMEN IN THE SUB DISTRICT UJUNG PANGKAH GRESIK, (2).

Rahayu, M. (2004). Efisiensi Pemasaran Buah Manggis di Kecamatan Lingsar, Lombok Barat.

Ruski. (2014). Pengaruh Program Bank Sampah Terhadap Tingkat Pendapatan Keluarga Nasabah Bank Sampah Lavender (BSL) Di Desa Mlajah Kabupaten Bangkalan. Ilmiah, 2(1), 1-166.

Samuelson, P. A. (1948). Economics: An Introductory Analysis. New York: McGraw-Hill.

Semaoen, I., \& Kiptiyah, S. M. (1997). Distribusi Pendapatan dan Kemiskinan di Desa Miskin Jawa Timur. Jurnal Penelitian Ilmu-Ilmu Sosial, 9. 
Sevilla, G. C. (1993). Pengantar Metode Penelitian. Jakarta: UI-Press.

Singh, I. (1986). Agricultural Household Models : Extensions Applications, And Policy, The John Hopkins. Univesrity Press, Baltimore.

Tadir, M., \& Trie. (2011). Yuk, Kita Peduli Sampah Sebagai Wujud Cinta Lingkungan. Jakarta: Nusa Jaya.

Todaro, M. (2000). Pembangunan Ekonomi di Dunia Ketiga (7th ed.). Jakarta.

Winardi, S. (1998). Kamus Ekonomi (Inggris-Indonesia). Bandung: PT. Mandar Maju. 